elements he destroyed the chemist's conception of the nature of atoms, and by doing so gave the atomic conception of matter a reality which it never had before. By his work on the scattering of alpha rays he removed the blots on the periodic system by removing its foundation and replacing it with something better. In doing so, he caused the development of a new and fruitful conception of valency. By his work on transmutation of elements he opened up an immense field of experimental work for the chemist, a field which few can doubt will yield results of the utmost importance in biology as well as in chemistry.
The secret of Rutherford's success in inspiring others lay not only in his genius but also in his unselfishness. Surely there was never a great man who gave so much credit to others. It was a pity, said Sir Henry Tizard, that Rutherford had no Boswell; that none of the men who worked in constant contact with him had made notes of his ways, of his sayings, of his few mistakes as well as his many successes ; of his manners, good and bad, and of his faults as well as of his virtues. Rutherford's name will live for ever in the history of our times as no man of science has ever lived before.

\title{
Electric Propulsion of Ships
}

$\mathrm{N}$ a paper read to the North-East Coast Institution 1 of Engineers and Shipbuilders at Newcastle-onTyne on December 16 by Mr. L. R. Horne, the development of the electric propulsion of ships was traced over the last hundred years.

In 1839, Yacobi made the first successful experiment. He built a boat capable of carrying twelve passengers and propelled it by an electric motor connected with a battery of 69 Grove cells. A speed of between two and three miles an hour was obtained. Owing to the imperfections in the motor, the idea did not receive any wide practical application and the experiment was soon forgotten. In 1882, an iron boat was electrically propelled on the Thames. In 1886, the Nautilus was built at Tilbury and fitted with twin screws driven by electric motors. In 1888, a submarine, the Gymnote, $59 \mathrm{ft}$. long and displacing 30 tons, was fitted with a 50-h.p. motor and attained a speed of eight miles per hour $(7 \mathrm{knots})$ The vessel was accepted by the French Navy. In the United States, in 1901, John P. Holland's submarine Holland VIII attracted attention and became the model on which Vickers submarines for the British Navy were first designed.

The most successful of the experiments in the early years of the century was made in Russia, and the machinery was constructed in Sweden by the firms now called the Atlas Diesel Co. and the A.S.E.A. This vessel was the M.S. Vandal, an 1100-ton shallowdraught tanker, built for service on the Volga and the Caspian Sea in 1903. The machinery consisted of three three-cylinder four-stroke cycle, single-acting engines, placed amidship, and each driving a dynamo and exciter, at 240 r.p.m. The propeller speeds could be varied from 30 to 300 r.p.m. with voltages up to 500. Reversal took 8-12 seconds. The weight of the engines, which were each rated at 120 h.p., was 48 tons, and that of the electrical equipment was 31 tons. The vessel continued in service for ten years, and similar installations followed.

So far, the development of electric propulsion was invariably associated with direct current machinery. During 1910-1911, Mr. Henry Mavor evolved from his experiments the passenger launch Electric Arc. This was probably the first experiment with alternating current for propulsion. A petrol engine of 45 h.p. was designed to run at 700 r.p.m. and was directly coupled to an alternator, which carried windings which gave four and six pole fields. Speeds of $7 \frac{1}{2}$ and 5 knots were obtained.

While European engineers may fairly claim that the initial stages of the development of the electric drive were the results of their inspiration and work, the most important landmark in its history was the decision of the U.S. Navy Department, shortly before the Great War, to utilize electric drive in its capital ships. Once it was convinced that the scheme was possible, the method was carried out boldly. Electric drive had been found practical with a.c. machinery up to 50 h.p., but at 600 h.p. it was not so good. Tests were made forthwith on a 7,000 h.p. collier and then on the electric propulsion of a battleship. The experimental installation was put in a twin-screw collier Jupiter (now an aircraft carrier called Langley), completed in 1913, and found most satisfactory. The battleship New Mexico, then under construction as a geared-turbine vessel, was consequently fitted with electric drive. A number of U.S. battleships and their two most powerful aircraft carriers have been provided with electric propelling machinery.

In Great Britain, in 1920, there was no enthusiasm for electric drive in any of its forms, but on this date one of the most conservative shipping companies ordered the Viceroy of India, and this ship with turboelectric drive and synchronous motors was a brilliant success. Service speeds of $18 \frac{1}{2}$ and 16 knots were given.

The climax of the development of electric drive, at least in the mercantile marine, came in 1935 with the commissioning of the Normandie. The machinery installation of this ship was designed for continuous operation at 160,000 h.p., and this power must have been exceeded when it steamed across the Atlantic at 31 knots.

In spite, however, of recent developments, the proportion of large new vessels installed with turboelectric drive is small. In the latest returns, record is made of forty-one vessels of 469,000 tons so propelled out of a total of 1,264 vessels of $9,439,000$ tons driven by turbines. The explanation would appear to be that, in general, owners prefer the type of machinery which they and their engineering staffs understand best.

In the field of small vessels, the rivalry between the different types of engines and systems of distribution is more intense and the successful progress of electric drive is more definite. A large proportion of vessels fitted with Diesel-electric drive are used in inland waters or are of less than 100 tons gross, or for some other reason are not included in classification returns. Probably there are about 250 vessels using Diesel-electric systems, and their total horse-power is of the order of 250,000 . The established success of electric tugs promises an increase in the number of small vessels so driven. 